\title{
Gangguan Koagulasi pada Sepsis
}

\author{
Tri Faranita, Yunnie Trisnawati, Munar Lubis \\ Departemen Ilmu Kesehatan Anak Fakultas Kedokteran Universitas Sumatra Utara, Medan
}

\begin{abstract}
Sepsis pada anak memiliki angka morbiditas dan mortalitas yang tinggi. Gangguan koagulasi berat pada sepsis berhubungan dengan meningkatnya mortalitas. Telah banyak informasi mengenai perkembangan mekanisme aktivasi koagulasi dan inflamasi sebagai respon terhadap infeksi berat. Pada sepsis, gangguan koagulasi terjadi akibat pembentukan trombin oleh tissue factor, gangguan mekanisme antikoagulan dan penghentian sistem fibrinolisis. Pengetahuan tersebut sangat berguna untuk mengembangkan terapi dan intervensi terhadap pasien dengan sepsis yang disertai gangguan koagulasi berat. Pemberian terapi seperti antikoagulan, antitrombin, dan rekombinan protein C, rekombinan TFPI masih memerlukan bukti yang mendukung untuk dapat digunakan pada pasien anak. Sari Pediatri 2011;13(3):226-32.
\end{abstract}

Kata kunci: sepsis, gangguan koagulasi, anak

S

epsis merupakan kumpulan gejala inflamasi sistemik yang disertai dugaan ataupun terbukti terdapat infeksi. Gejala inflamasi sistemik tersebut ditandai oleh dua atau lebih abnormalitas pada suhu, jumlah leukosit, takikardi dan takipnu. ${ }^{1,2}$ Sepsis pada anak memiliki angka morbiditas dan mortalitas yang tinggi sehingga menjadi alasan utama untuk memasukkan anak ke ruang rawat intensif. ${ }^{2}$ Angka kejadian sepsis berat pada anak di Amerika Serikat 0,56 kasus per 1000 populasi per tahun dengan insidens tertinggi pada bayi yaitu 5,16 kasus per 1000 populasi dengan mortalitas sekitar $10,3 \% .^{3}$ Gangguan koagulasi pada sepsis

\section{Alamat korespondensi:}

Dr. Tri Faranita. Departemen Ilmu Kesehatan Anak FK-USU/ RSUP.H.Adam Malik Medan. Jl. Bunga Lau No. 17 Medan - 20136, Telp. (061) 8361721 - 8365663. Fax. (061) 8361721. E-mail: faranita. md@gmail.com dapat bervariasi dari aktivasi koagulasi yang hanya terdeteksi oleh marker sensitif hingga disseminated intravascular coagulation (DIC). ${ }^{4}$ Insidens DIC pada sepsis berat berkisar antara 14\% hingga 32\% dan berhubungan dengan meningkatnya mortalitas pada sepsis. ${ }^{5}$ Informasi mengenai mekanisme aktivasi koagulasi dan inflamasi sebagai respon terhadap infeksi berat telah banyak mengalami perkembangan. ${ }^{4,6}$ Pengetahuan tentang hal tersebut sangat berguna untuk mengembangkan terapi dan intervensi terhadap pasien dengan sepsis yang disertai gangguan koagulasi berat. $^{6}$

\section{Fisiologi koagulasi}

Sistem hemostasis dipertahankan oleh interaksi antara sel endotel, protein koagulasi,dan trombosit sebagai tiga unsur utama untuk menjaga fluiditas darah pada keadaan normal. Pada keadaan cedera, ketiga unsur 


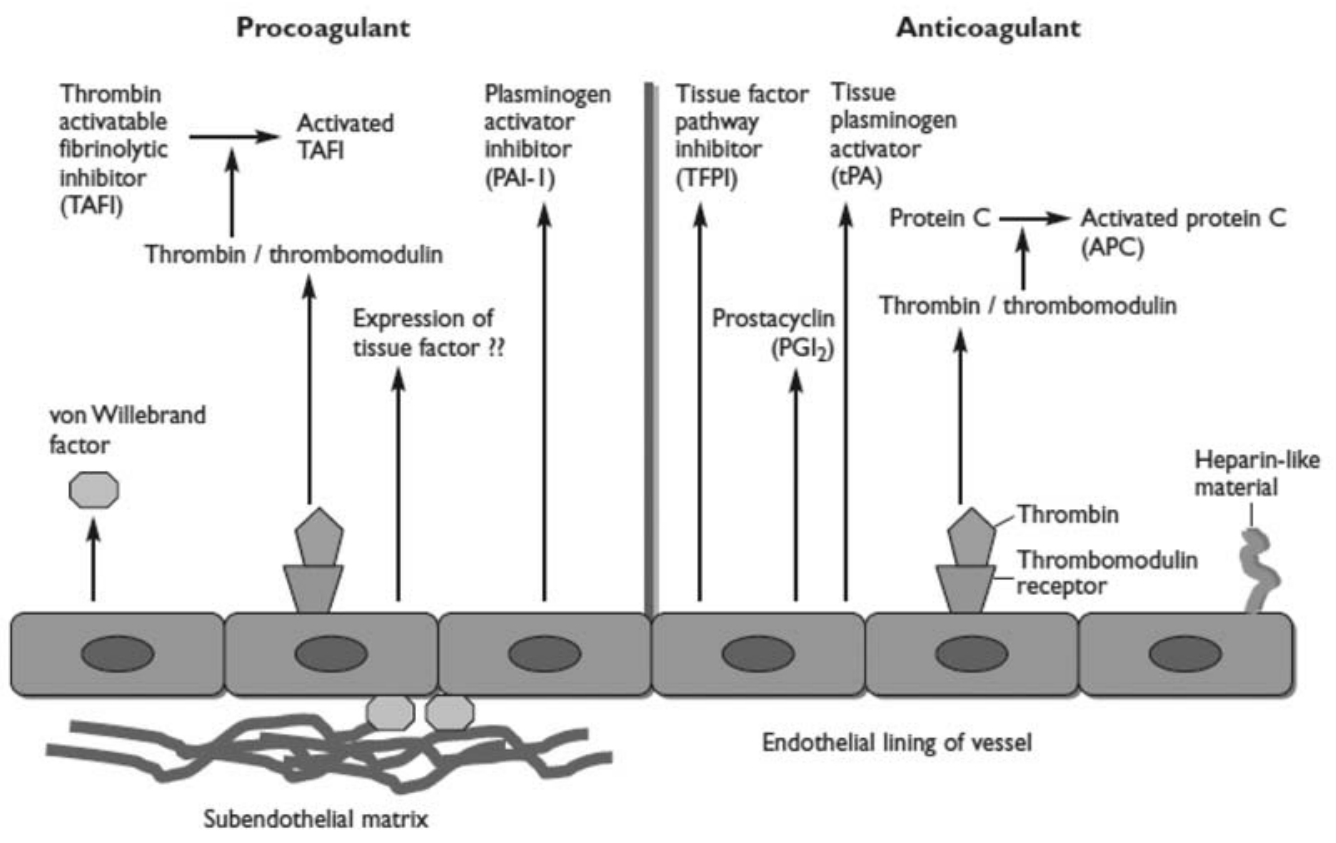

Gambar 1. Fungsi endotel pada prokoagulasi dan antikoagulasi

Dikutip dari: Leftkowitz JB. Coagulation pathway and physiology. 2008.7

utama tersebut bekerjasama dalam sistem koagulasi. ${ }^{7}$ Sel endotel merupakan lapisan dalam pembuluh darah yang non trombogenik. ${ }^{8}$ Fungsi sel endotel dalam sistem hemostasis (Gambar 1) antara lain mensintesis tissue factor (TF), tempat penyimpanan faktor von Willebrand, berperan pada sistem fibrinolisis dengan menghasilkan plasminogen activator inhibitor (PAI-I) dan memiliki reseptor thrombomodulin. Apabila PAI-I berikatan dengan thrombin dapat mengaktivasi thrombin activatable fibrinolytic inhibitor (TAFI), dan berperan pada sistim antikoagulan dengan menghasilkan tissue factor pathway inhibitor (TFPI), tissue plasminogen activator (tPA), prostacyclin $\left(\mathrm{PGI}_{2}\right)$, mengaktivasi protein C. Pada permukaan sel endotel terdapat heparin-like materialyang merupakan kofaktor antitrombin. ${ }^{78}$ Trombosit merupakan sel yang sangat berperan pada proses koagulasi. ${ }^{9}$ Trombosit berinteraksi dengan komponen matriks ekstrasel disaat terjadinya cedera sehingga terbentuk platelet plug sebagai penutup lesi pembuluh darah. ${ }^{7,8}$ Trombosit yang teraktivasi juga menghasilkan berbagai agonis trombosit yang memperantarai kontraksi otot polos sehingga terjadi vasokonstriksi. $^{8}$

Sejak tahun 1960-an diperkenalkan kaskade koagulasi melalui jalur intrinsik dan jalur ekstrinsik.
Model kaskade koagulasi memberi kesan bahwa kedua jalur tersebut bekerja terpisah, namun manifestasi klinis menyangkal konsep tersebut. ${ }^{9,10}$ Sekitar limabelas tahun yang lalu timbul hipotesis baru untuk memahami proses hemostasis. Model koagulasi berbasis sel (cell-based model of coagulation) menyatakan bahwa koagulasi muncul pada tahapan yang overlapping yaitu inisiasi, amplifikasi, dan propagasi (Gambar 2)..$^{8-10}$

Tahap inisiasi dimulai pada sel yang dapat mengekspresikan tissue factor (TF). membentuk kompleks dengan faktor VIIa dan mengaktivasi faktor IXa dan Xa. Faktor Xa berikatan dengan faktor Va pada permukaan sel dan menghasilkan trombin dengan jumlah sedikit. Faktor Xa segera diinhibisi sehingga tidak dapat bergerak ke sel yang lain. ${ }^{9,10}$ Tahap amplifikasi dimulai setelah munculnya cedera, trombosit keluar dari pembuluh darah sehingga terjadi perlekatan trombosit dengan trombin yang dihasilkan pada tahap inisiasi. ${ }^{10}$ Trombin mengaktivasi trombosit sehingga terjadi perubahan permukaan dan pengeluaran faktor $\mathrm{V}$ yang sebagian aktif. Trombin juga mengaktivasi kofaktor $\mathrm{V}$ dan VIII, ${ }^{11}$ serta mengaktivasi faktor XI menjadi faktor $\mathrm{XIa} .{ }^{12}$ Tahap propagasi berlangsung pada permukaan 


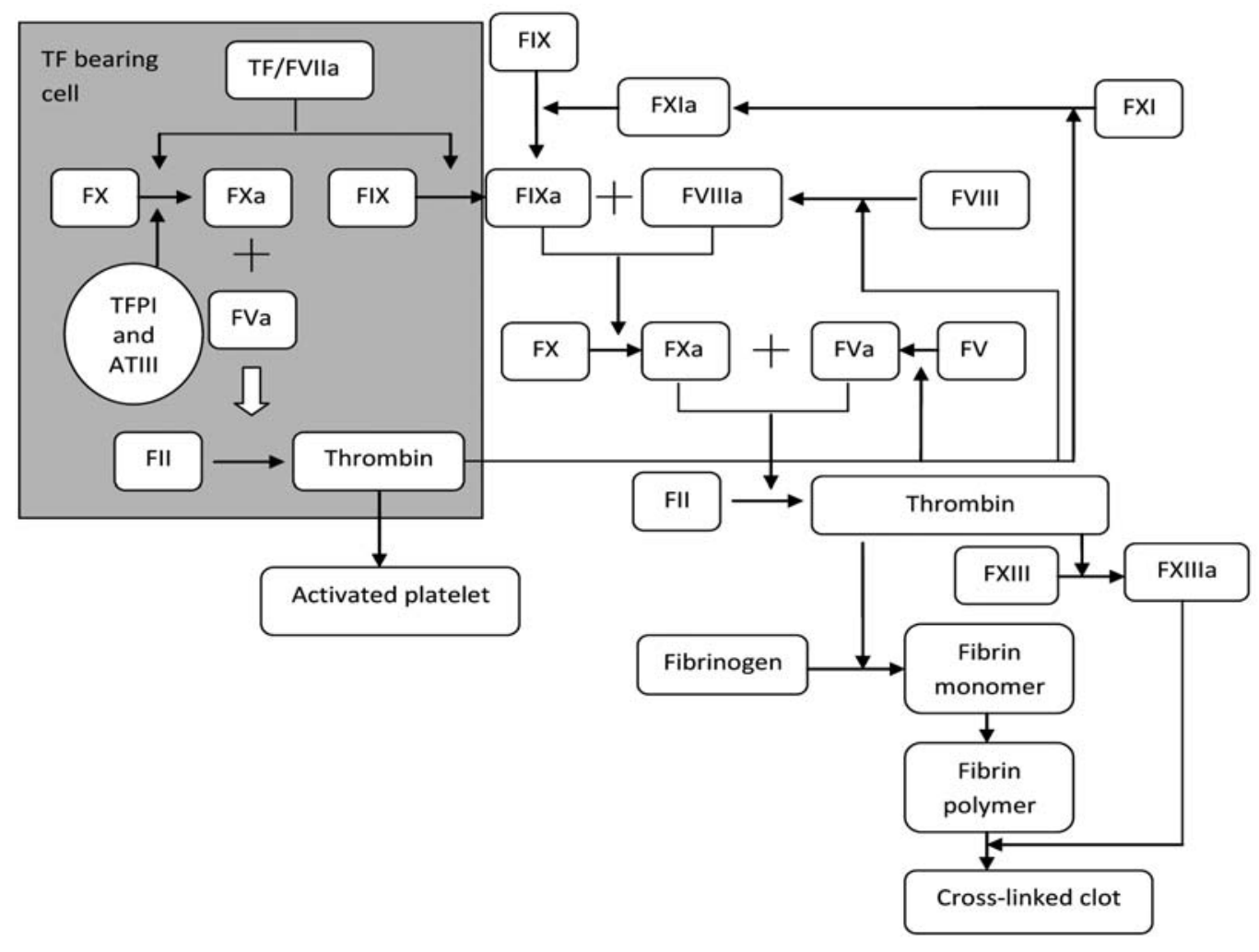

Gambar 2. Model koagulasi berbasis sel

Dikutip dari: 1. Leftkowitz JB. Coagulation pathway and physiology, 2008. ${ }^{7}$

2. Hoffman M. Remodelling the blood coagulation cascade, $2003^{9}$

trombosit yang teraktivasi. ${ }^{9}$ Pada tahap ini FIXa berikatan dengan VIIIa, ${ }^{10}$ jumlah FIXa bertambah dari hasil ikatan trombosit dengan FXIa. ${ }^{11}$ Kompleks FIXa/VIIIa mengaktivasi FXa pada trombosit dan segera berikatan dengan FVa sehingga mengubah protrombin menjadi thrombin, ${ }^{9,10}$ selanjutnya pembentukan trombin mengubah fibrinogen menjadi fibrin. ${ }^{10}$

Setelah bekuan fibrin terbentuk, harus terdapat mekanisme untuk membatasi jumlah bekuan fibrin dan pelepasan bekuan saat cedera sembuh. Untuk mengontrol pembentukan bekuan fibrin terdapat tiga mekanisme yaitu TFPI, mekanisme antitrombinheparin, dan jalur antikoagulan protein C. ${ }^{6}$ Sedangkan yang bertanggung jawab dalam pelepasan dan degradasi bekuan fibrin adalah sistem fibrinolisis. Plasmin berperan penting pada fibrinolisis dan dikatalisasi oleh tPA atau urokinase-type plasminogen activator (uPA). Inhibitor pada sistem fibrinolisis adalah PAI-1 dan antiplasmin. ${ }^{7}$

\section{Patofisiologi koagulasi pada sepsis}

Gangguan koagulasi pada sepsis terjadi melalui tiga mekanisme (Gambar 3),

1. Pembentukan trombin yang diperantarai TF Tranfer factor diekspresikan pada permukaan sel endotel, monosit, dan platelet ketika sel-sel ini distimulasi oleh toksin, sitokin atau mediator lain. ${ }^{13}$ Adanya endotoksin menyebabkan peningkatan beberapa sitokin proinflamasi seperti tumor necrosis factor (TNF)- $\alpha$ dan interleukin (IL)-6. Sitokin IL-6 merupakan sitokin proinflamasi yang paling berhubungan dengan klinis sepsis dan komplikasi. ${ }^{14}$ Pembentukan trombin yang diperantarai oleh TF merupakan tahap penting dari patogenesis sepsis. Secara fisiologis pembentukan ini segera dihambat oleh antitrombin, namun dengan pembentukan trombin yang sangat cepat jalur inhibisi ini bisa fatigue sehingga terjadi trombinemia. ${ }^{13}$ Setelah trombin terbentuk maka fibrinogen 
dipolimerasi sehingga terbentuk bekuan fibrin dan terdeposisi di mikrosirkulasi. Deposisi fibrin ini dapat menyebabkan disfungsi organ. ${ }^{13,15}$

2. Gangguan mekanisme antikoagulan Terdapat tiga mekanisme antikoagulan yang terganggu pada sepsis,

a. Sistem antitrombin

Secara teori antitrombin memiliki peran penting dalam kekacauan koagulasi pada sepsis, ${ }^{4}$ dibuktikan dengan jumlah antitrombin rendah pada sepsis. ${ }^{4,16}$ Jumlah antitrombin berkurang disebabkan karena antitrombin digunakan untuk menghambat formasi trombin, didegradasi oleh elastase yang dilepaskan sel neutrofil serta gangguan sintesis antitrombin akibat gagal hati pada sepsis. , $^{43,16}$

b. Sistem protein $\mathrm{C}$

Protein $\mathrm{C}$ disintesis di hati dan diaktivasi menjadi activated protein $C$ (APC) yang berfungsi dalam menghambat FVIII dan FV. ${ }^{13}$ Pada sepsis, terjadi depresi sistem protein $\mathrm{C}$ yang disebabkan oleh penggunaan yang berlebihan, gangguan hati, perembesan vascular, dan aktivasi TNF- $\alpha .{ }^{4,16}$ c. Tissue factor pathway inhibitor (TFPI)

Tissue factor pathway inhibitor disekresi oleh sel endotel dan berfungsi untuk menghambat aktivasi FX oleh kompleks TF-FVIIa. ${ }^{13}$ Penurunan TFPI dapat dijumpai pada sepsis. ${ }^{4}$

3. Penghentian sistem fibrinolisis

Pada kondisi bakteremia dan endotoksemia dijumpai peningkatan aktivitas fibrinolisis yang mungkin disebabkan oleh pelepasan plasminogen activator oleh sel endotel. Keadaan tersebut diikuti dengan supresi aktivitas fibrinolisis secara cepat oleh PAI- $1 .{ }^{16}$ Jumlah PAI-1 yang tinggi dipertahankan sehingga menghentikan kemampuan fibrinolisis yang mengakibatkan penumpukan bekuan fibrin pada mikrosirkulasi. ${ }^{13}$

Pada sepsis terjadi trombositopenia pada pasien berat. Faktor utama yang menyebabkan penurunan jumlah trombosit pada sepsis adalah produksi trombosit yang terganggu, peningkatan pemakaian maupun destruksi, atau sekuestrasi trombosit di limpa. ${ }^{17}$

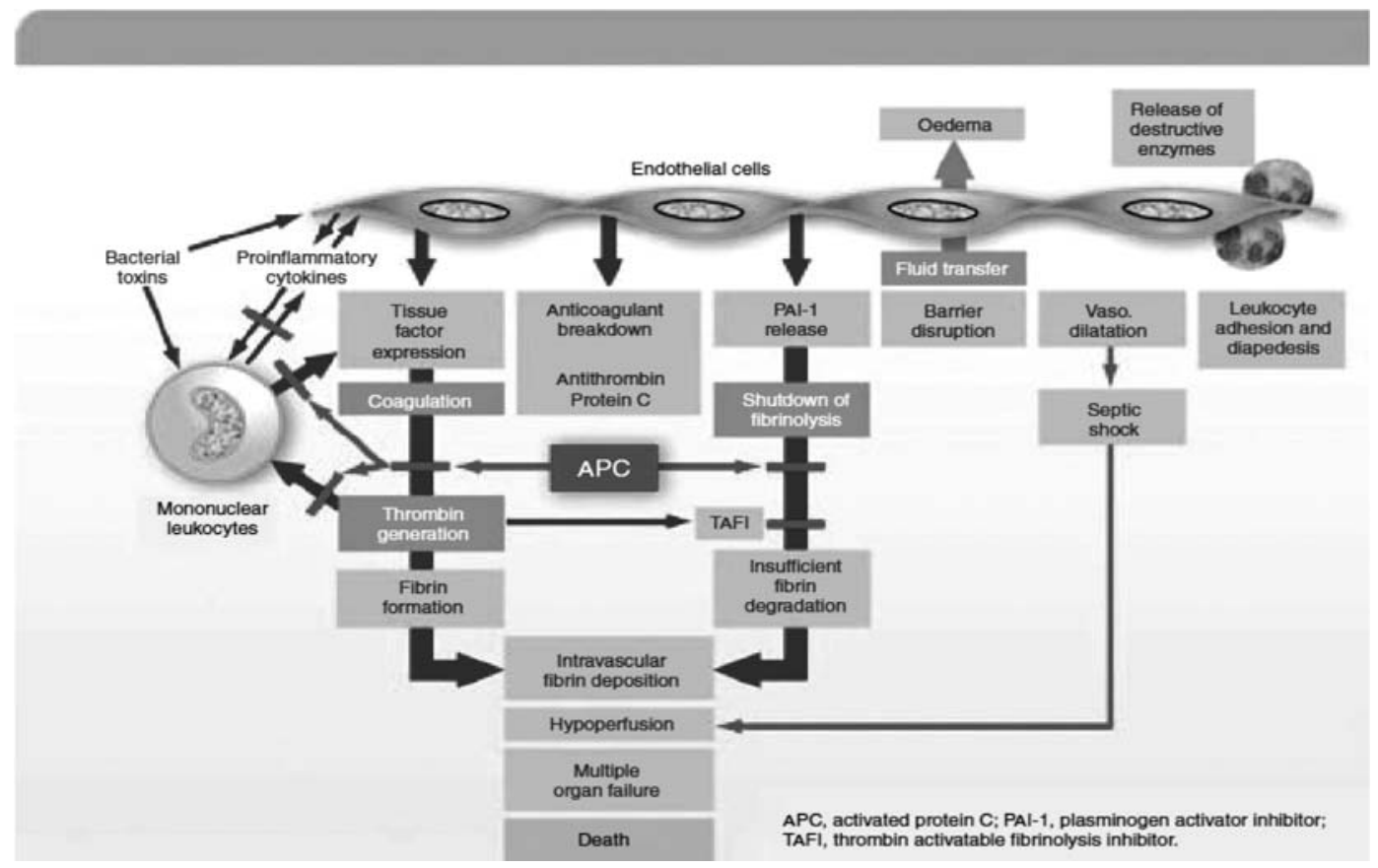

Gambar 3. Patofisiologi sepsis

Dikutip dari: Franchini M, Lippi G, Manzato F. Recent acquisitions in the pathophysiology, diagnosis and treatment of disseminated intravascular coagulation, $2006^{16}$ 


\section{Gambaran klinis koagulopati pada sepsis}

Gambaran klinis koagulopati pada sepsis ialah,

1. Aktivasi koagulasi sistemik fisiologis

Pada kondisi awal tidak tampak klinis koagulopati, namun proses koagulasi mulai teraktivasi dan terdeteksi melalui pengukuran marker molekular yang sensitif seperti D-dimer, protrombin fragmen $1+2$, atau kompleks trombin-antitrombin. ${ }^{13}$

2. Non-overt disseminated intravascular coagulation Sedangkan tahap selanjutnya ditandai dengan pembentukan fibrin intravaskular yang menyebabkan gangguan pada mikrosirkulasi. Hasil laboratorium menunjukkan peningkatan marker aktivasi namun pemeriksaan lain masih normal. ${ }^{13}$

3. Transient consumption coagulopathy

Jika rangsangan prokoagulasi tetap terjadi maka akan terjadi ketidakseimbangan antara penggunaan plasma protein koagulasi dan sintesis di hati. Apabila rangsangan dihentikan dengan menghilangkan penyebabnya maka gangguan tersebut dapat teratasi dalam beberapa jam hingga beberapa hari. ${ }^{13}$ Hasil laboratorium menunjukkan peningkatan prothrombine time (PT), trombosit menurun, jumlah protein $\mathrm{C}$ menurun, fibrinogen dapat normal maupun menurun. ${ }^{13}$

4. Overt DIC

Proses berkelanjutan sampai koagulopati konsumtif berat jarang dijumpai. Gangguan tersebut ditandai dengan penghentian mekanisme inhibisi sehingga hemostasis tidak terkontrol dan menyebabkan perdarahan berat. ${ }^{13}$ Manifestasi klinis DIC yang paling sering adalah perdarahan, trombosis atau keduanya yang dapat menyebabkan disfungsi organ. Pada pemeriksaan laboratorium dapat dijumpai peningkatan waktu pembekuan darah, peningkatan fibrin degradation product (FDP), D-dimer, penurunan trombosit dan kadar fibrinogen, penurunan kadar faktor koagulasi (seperti faktor V dan VIII), dan penurunan penghambat koagulasi (antitrombin dan protein C). Pemeriksaan koagulasi serial akan lebih baik dalam mendiagnosis DIC. ${ }^{16}$

5. Purpura fulminans

Purpura fulminans merupakan bentuk koagulopati akibat sepsis yang berupa lesi kulit dengan morfologi yang khas karena trombosis pembuluh darah kecil dan kapiler yang menghasilkan nekrosis dan perdarahan sekunder. Lesi tersebut berhubungan dengan kerusakan sistem protein $\mathrm{C}$ di mikrosirkulasi. ${ }^{16}$

\section{Tata laksana gangguan koagulasi pada sepsis}

Gangguan koagulasi pada sepsis akan dapat diatasi jika penyebab sepsis diatasi. Pada gangguan koagulasi yang berat sampai tahap DIC pengobatan yang diberikan dapat berupa,

1. Terapi pengganti

Tujuan dari pemberian terapi pengganti adalah untuk menggantikan defisiensi akibat penggunaan konsentrat trombosit faktor koagulasi dan inhibitor, untuk mencegah perdarahan. ${ }^{16}$ Pemberian konsentrat trombosit dan faktor koagulasi tidak hanya didasari dengan hasil laboratorium namun kecenderungan pasien mengalami perdarahan. ${ }^{18}$

2. Antikoagulan

Penghentian koagulasi pada pasien DIC memberi manfaat secara teori. Keamanan heparin pada pasien DIC yang cenderung mengalami perdarahan menjadi perdebatan, walaupun pemberian heparin tidak terbukti meningkatkan insidens komplikasi perdarahan. ${ }^{19}$ Pemberian heparin mungkin dapat berguna pada pasien DIC akut dan tromboembolisme predominan seperti dengan purpura fulminans. ${ }^{16,19}$ Penelitian agen antikoagulan baru dengan aktivitas penghambat trombin secara langsung yaitu rekombinan hirudin pada kelinci dalam mengobati DIC menunjukkan pengurangan konsumsi trombosit, fibrinogen, antitrombin, dan protein $\mathrm{C}$ serta menurunkan mortalitas. Penggunaan rekombinan tersebut pada manusia masih memerlukan penelitian lanjutan. ${ }^{20}$

3. Pengembalian jalur antikoagulan

Antitrombin merupakan penghambat utama trombin, penggunaan pada DIC cukup rasional. ${ }^{16}$ Penurunan jumlah antitrombin berhubungan dengan prognosis yang buruk pada pasien sepsis. Studi di Italia memperlihatkan bahwa pemberian antitrombin memiliki dampak yang menguntungkan dalam hal kelangsungan hidup. ${ }^{21}$ Namun pada penelitian yang dilakukan pada 2144 pasien sepsis dan DIC tidak dijumpai dampak yang sama. ${ }^{22}$ 
Sistem protein $\mathrm{C}$ ikut terganggu pada DIC, dan APC tampak memiliki peran dalam patogenesis sepsis yang berhubungan dengan disfungsi organ. Sebuah studi yang dilakukan di sebelas negara pada kasus sepsis menunjukkan terdapat perbaikan klinis pada pasien yang mendapat konsentrat APC. Penurunan mortalitas $40 \%$ dijumpai pada pasien yang mendapat dosis lebih tinggi, ${ }^{23}$ namun pemberian konsentrat APC pada anak sepsis berat belum terbukti memberikan manfaat. ${ }^{24}$

Penghambat mekanisme pembentukan trombin lainnya adalah TFPI. Rekombinan TFPI telah luas diteliti pada pasien sepsis dan peningkatan kadar TFPI dapat tercapai namun manfaatnya dalam menurunkan mortalitas dan perbaikan disfungsi organ belum terbukti. ${ }^{25}$

4. Agen lain

Rekombinan FVIIa mungkin dapat digunakan pada pasien dengan perdarahan berat yang tidak respon terhadap terapi lain. ${ }^{16}$ Namun penelitian retrospektif terhadap penggunaan rekombinan pada pasien anak sepsis dan DIC menunjukkan tidak ada manfaat yang bermakna. ${ }^{26}$ Agen antifibrinolitik seperti asam traneksamat tidak boleh diberikan kecuali sebelumnya telah diberi infus heparin. ${ }^{16}$

\section{Daftar pustaka}

1. Goldstein B, Giroir B, Randolph A. International pediatric consensus conference: definitions for sepsis and organ dysfunction in pediatrics. Pediatr Crit Care Med 2005; 6:2-8.

2. Thomas NJ, Tamburro RF, Hall MW, Rajasekaran $S$, Venglarcik JS. Bacterial sepsis and mechanisms of microbial pathogenesis. Dalam: Nichols DG, penyunting. Roger's textbook of pediatric intensive care. Philadelphia: Lippincott Williams \& Wilkins; 2008. h.1300-27.

3. Watson RS, Carcillo JA, Linde-Zwirble WT, Clermont G, Lidicker J, Angus DC. The epidemiology of severe sepsis in children in the united states. Am J Respir Crit Care Med 2003; 167:695-701.

4. Levi M, De Jonge E, Poll T. Rationale for restoration of physiological anticoagulant pathways in patients with sepsis an disseminated intravascular coagulation. Crit Care Med 2001; 29 Suppl 7:90-4.
5. Levi M. Pathogenesis and treatment of disseminated intravascular coagulation in the septic patient. J Crit Care 2001; 4:167-77.

6. Levi M, Schultz M, Poll T. Disseminated intravascular coagulation in infectious disease. Semin Thromb Hemost 2010; 36:367-77.

7. Leftkowitz JB. Coagulation pathway and physiology. Dalam: Kotte-Marchant K, penyunting. An algorithmic approach to hemostasis testing. Washington: College of American Pathologists Press; 2008.h.3-12.

8. Verhamme P, Hoylaerts MF. The pivotal role of the endothelium in haemostasis and thrombosis. Acta Clin Belg 2006:61-5.

9. Hoffman M. Remodelling the blood coagulation cascade. J Thromb Thrombolysis 2003; 16:17-20.

10. Smith SA. The cell-based model of coagulation. J Vet Emerg Crit Care 2009; 19:3-10

11. Roberts HR, Hoffman M, Monroe DM. A cell-based model of thrombin generation. Semin Thromb Hemost 2006; 32 Suppl 1:32-8.

12. Oliver JA, Monroe DM, Roberts HR, Hoffmann M. Thrombin activates factor XI on activated platelets in the absence of factor XII. Arterioscler Thromb Vasc Biol 1999; 19:170-7.

13. Knoebl P. Blood coagulation disorders in septic patients. Wien Med Wochenschr 2010; 160:129-38.

14. Damas P, Ledoux D, Nys M. Cytokine serum level during severe sepsis in human IL-6 as a marker of severity. Ann Surg 1992; 215:356-62.

15. Saba HI, Morelli GA. The pathogenesis and management of disseminated intravascular coagulation. Clin Adv Hematol Oncol 2006; 4:919-26.

16. Franchini M, Lippi G, Manzato F. Recent acquisitions in the pathophysiology, diagnosis and treatment of disseminated intravascular coagulation. Thrombosis Journal 2006;4:4-12.

17. Levi M, Opal SM. Coagulation abnormalities in critically ill patients. Crit Care 2006; 10:222-30.

18. Levi M. Disseminated intravascular coagulation in cancer patients. Best Pract Res Clin Haematol 2009; 22:12936.

19. Levi M, ten Cate H. Disseminated intravascular coagulation. N Engl J Med 1999; 341:586-92.

20. Munoz MC, Montez R, Hermida J, Orbe J, Paramo A, Rocha E. Effect of the administration of recombinant hirudin and/or tissue-plasminogen activator (t-PA) on endotoxin-induced disseminated intravascular coagulation model in rabbits. Br J Haematol 1999; 105:117-22. 
21. Baudo F, caimi TM, de Cataldo F. Antithrombin III (ATIII) replacement therapy in patients with sepsis and/or post-surgical complications: a controlled, double blind, randomized controlled trial. Int Care Med 1998; 24:336-42.

22. Warren BL, Eid A, Singer P. High-dose antithrombin III in severe sepsis: a randomized controlled trial. JAMA 2001; 286:1869-78.

23. Bernard GR, Vincent JL, Laterre PF. Efficacy and safety of recombinant human activated protein $\mathrm{C}$ for severe sepsis. N Engl J Med 2001; 344:699-709.
24. Nadel S, Goldstein B, Williams MD. Drotrecogin alfa (activated) in children with severe sepsis: a multicentre phase III randomized controlled trial. Lancet 2007;369:836-43.

25. Abraham E, Reinhart K, Opal S. Efficacy and safety of tifacogin (recombinant tissue factor pathway inhibitor) in severe sepsis a randomized controlled trial. JAMA 2003;290:238-47.

26. Alten JA, Benner K, Green K, Toole B, Tofil NM, Winkler MK. Pediatric off-label use of recombinant factor VIIa. Pediatrics 2009;123:1066-72. 